\title{
EFFECTS OF ETHANOL CINCAU (CYCLEA BARBATA MIERS) LEAVES EXTRACT ON MACROPHAGE MIGRATION ON BURN WOUND
}

\section{DINA DEWI S L I I,2*, WIBI RIAWAN ${ }^{3}$, IKA SETYO RINI ${ }^{1}$, TITIN ANDRI WIHASTUTI ${ }^{1}$, IKA FITRI APRILIANTI ${ }^{1}$, RETTY RATNAWATI ${ }^{4}$, HANDONO KALIM ${ }^{5}$, KARYONO MINTAREOM ${ }^{6}$, LOEKI ENGGAR FITRI $^{7}$}

\begin{abstract}
${ }^{1}$ Department of Nursing, Faculty of Medicine Universitas Brawijaya, Malang, Indonesia. ${ }^{2}$ Student of Doctoral Program of Medical Science of Faculty of Medicine Universitas Brawijaya, Malang, Indonesia. ${ }^{3}$ Department of Biochemistry, Faculty of Medicine Universitas Brawijaya, Malang, Indonesia. ${ }^{4}$ Department of Physiology, Faculty of Medicine Universitas Brawijaya, Malang, Indonesia. ${ }^{5}$ Department of Internal Medicine, Faculty

of Medicine University Brawijaya, Malang, Indonesia. ${ }^{6}$ Department of Pathology Anatomy, Faculty of Medicine University Brawijaya, Malang,

Indonesia. ${ }^{7}$ Department of Parasitology, Faculty of Medicine Universitas Brawijaya, Malang, Indonesia.Email: dinadewisli@gmail.com
\end{abstract}

Received: 31 January 2019, Revised and Accepted: 01 April 2019

ABSTRACT

Objective: Macrophages are essential cells in burn wound healing. The primary function of macrophages is phagocytosis of microbes and necrosis tissue. Migration of macrophages into the wound area is affected by interleukin-1 (IL-1). Ethanol extract of Cincau or green grass jelly leaves or Cyclea barbata Miers contains pectin, flavonoids, and alkaloids. These compounds influence the inflammatory process. The purpose of this study was to reveal the effect of ethanol Cincau leaves extract on the expression of IL-1 and the number of macrophages in second degree burn wounds tissue.

Methods: This study used 30 rats divided into six groups based on different treatments: $\mathrm{NaCl} 0.9 \%$ (K), silver sulfadiazine/(SSD) (P1), hydrogels (P2), Cincau extract $40 \%$ (P3), Cincau extract 50\% (P4), and Cincau extract 60\% (P5). Treatment was conducted over 4 days. On the $5^{\text {th }}$ day, burn wounds tissues were taken, then immunohistochemistry staining was applied.

Results: One-way ANOVA test on the expression of IL-1 showed a difference among groups $(\mathrm{p}<0.05)$ and on the number of macrophages $(\mathrm{p}<0.05)$. Post hoc tests on the expression of IL- 1 showed Cincau extracts $40 \%$ and $50 \%$ treated-groups significantly differ with the NaCl $0.9 \%$ group but not with hydrogel treated group. The similar result showed Cincau extracts $40 \%$ and $50 \%$ treated-groups significantly differ from the control group but not with SSD and hydrogel groups.

Conclusions: It can be concluded that ethanol extract of Cincau leaves can decrease IL-1 expression and increase the number of macrophages which have an important role in inflammation resolution of burn wounds.

Keywords: Green grass jelly leaves (Cyclea barbata Miers), Interleukin-1, Macrophages, Burn wound, Cincau.

(C) 2019 The Authors. Published by Innovare Academic Sciences Pvt Ltd. This is an open access article under the CC BY license (http://creativecommons. org/licenses/by/4. 0/) DOI: http://dx.doi.org/10.22159/ajpcr.2019.v12i5.32296

\section{INTRODUCTION}

Burn is a trauma that can be suffered by people in all ages and genders [1]. Although burn incidences have been declining globally, the prevalence of burn in Indonesia is quite high [1]. Previous research in Cipto Mangunkusumo Hospital showed that burns had high morbidity and mortality [2]. Moreover, burns require special treatment from the early phase to the late phase.

The degree of burn is divided based on the depth of the skin layer suffered from the injury; the first degree (superficial), second degree (partial thickness), and third degree (full thickness) [3]. A seconddegree burn is divided into $2 \mathrm{~A}$ and $2 \mathrm{~B}$ stages. In the $2 \mathrm{~B}$-degree burn, almost the whole of the dermis is damaged (two-thirds of the layers are damaged) [3]. Skin appendices such as hair follicles, sweat glands, and sebaceous glands are partially intact. In addition, the 2B degree burns often encountered thin eschar. Eschar is dead tissue or denatured proteins that are firmly attached to the tissue and increase the risk of infection, which will prolong the inflammation period and lead delay wound healing [4].

Burn healing process begins with the inflammatory phase, which consists of the initial inflammatory and late inflammatory [5]. Inflammation usually occurs in 3-7 days [6]. In the late inflammatory phase, the pro-inflammatory mediators such as Interleukin-1 (IL-1) decreased [7] to achieve a resolution of inflammation. In the late inflammatory phase, the dominant cells are macrophages [6]. The primary function of macrophages is to clean foreign particles from the body, such as bacteria, necrotic tissue, and other foreign objects [6]. The increase in both the number and the activity of macrophages would help the elimination of necrotic tissue in burns (eschar) [7]. This mechanism is known as autolysis debridement [8]. The increase in the number of macrophages migration into the wound site would improve the process of autolysis debridement. Enhanced macrophage migration can be improved by keeping the wound surface moist; thus, enabling the surface of the wound treatment material required in maintaining the moisture balance in the wound surface $[3,7]$.

The well-known topical therapy for burn treatment is $\mathrm{NaCl} 0.9 \%$, silver sulfadiazine (SSD) and hydrogel. $\mathrm{NaCl} 0.9 \%$, an isotonic fluid for irrigation and compress the wound, but it has a weakness when applied as a compress due to its volatility [9]. SSD cream $1 \%$ is water soluble, which is bactericidal but lack of ability to penetrate [10]. SSD also has several side effects such as leucopenia, argyria, and crystalluria [10]. The hydrogel is a wound treatment material which is a type of absorptive dressings type [11]. Hydrogels are macro-molecules that can absorb liquid, reduce pain, and give a cooling effect $[11,12]$. The main component of hydrogels is insoluble hydrophilic material [13]. Hydrogel helps burns by softening necrotic tissue, absorbing exudates, and retaining moisture wound base [14]. Unfortunately, the hydrogel has limited availability in the community due to its high prices. In overcoming this problem, an alternative wound topical therapy is 
needed. It should have a prime ability and low price. One natural herbal with a close ingredient with hydrogel is green grass jelly or Cincau leaves Cyclea barbata Miers (CBM) [15].

Cincau leaves have been used as a remedy for fever in chronic wounds and high blood pressure. Cincau leaf extract also has the ability to increase lymphocyte cells proliferation and increase the proliferation of lymphocyte cells at a relatively low dose, i.e., $<0.12 \mathrm{mg} / \mathrm{ml}$ [13]. It can soften the stool for a long time. Cincau commonly grows in moist and shady areas [16]. This plant is easily cultivated and grows wild [16]. Substances contained in the Cincau are alkaloids, flavonoids, and polysaccharide pectin [15-19]. Alkaloids and flavonoids are antioxidants compounds that function as an immune stimulant to macrophages and scavenger of the free radicals in burns $[18,19]$. Polysaccharide pectin can configure gels that have the ability to absorb the surrounding fluid. Cincau gel is hydrophilic and capable of serving cool effect and retaining moisture wound area as well as CMC $[18,20]$. Pectin also acts as anti-inflammatory agent by influencing mitogen-activated protein kinases signaling pathway to control inflammation processes [21]. Therefor presumed that Cincau can be afforded macrophage number in burn wound. The research novelty was the addition of Cincau extract effect toward macrophage number in burn wound. So that leaves grass jelly has the potential to be expanded as an alternative treatment for a burn in the future.

\section{METHODS}

This study was a true experimental post-test only control group design. The samples were 30 male rats (Rattus norvegicus) divided into six groups; control group, group that was treated with $\mathrm{NaCl} 0.9 \%(\mathrm{~K})$, group that was treated with SSD (P1), group that was treated with a hydrogel (P2), and 3 treatment groups that were treated with the ethanol extract of Cincau leaves CBM with concentration of 40\% (P3), $50 \%$ (P4), and 60\% (P5), respectively. This research was approved by the Ethical Clearance Committee in the Medical Faculty of Brawijaya University; the approval was listed in the approval letter of ethical clearance with number 524/EC/KEPK-PSIK/11. This study was conducted for 4 days. The rats were terminated on the $4^{\text {th }}$ day after wound creation.

\section{Creation of second-degree burn}

First, anesthesia was performed intramuscularly in the lower abdomen of the experimental rats using ketamine with a dose of $\pm 5 \mathrm{mg}$ diluted in $0.5 \mathrm{ml}$ water for injection to each mouse The upper right back area was determined as an induced area for second-degree burn, next, the hair on the area was cleaned and shaved. The burn wound was created based on a preliminary study; the $2 \mathrm{~cm} \times 2 \mathrm{~cm}$ with $2 \mathrm{~mm}$ thickness iron plate was heated until the temperature reached $80^{\circ} \mathrm{C}$. This process was done for \pm 8 min using a bunsen flame that is already set on the axis of $1 \mathrm{~cm}$ high. An iron plate was then attached to the determined area in the back of the rat for $6 \mathrm{~s}$ with minimal pressure. After the iron plate was appointed, then wound was bathed with $0.9 \% \mathrm{NaCl}$ for $60 \mathrm{~s}$. The wound was dried using sterile gauze and bandaged.

\section{Burn wound care}

After hand washing was done, the pad was placed on the bottom, and the wound care set was put close to the wound. Then, the rat was held as comfortable as possible by placing the wound up to facilitate wounds handling. Smeltzer et al. explained that wound care procedure was contained several steps [22]. First, the wound was irrigated with $\mathrm{NaCl}$ $0.9 \%$ to facilitate the easy opening of the dressing. Using sterile gloves, the wound was cleaned using $\mathrm{NaCl} 0.9 \%$ and dried with sterile gauze. Finally, the wound was applied with the treatment materials and then bandaged.

\section{Green Cincau extract}

As mentioned by Rahayu et al., Cincau leaves were extracted using the maceration technique [23]. Dry Cincau leaves were very smoothly mashed in a blender. Next, $100 \mathrm{~g}$ of Cincau leaves powder were put in a $1 \mathrm{~L}$ Erlenmeyer glass. Then, leaves were soaked in ethanol to a volume of $1000 \mathrm{ml}$, then shaken until thoroughly mixed ( $\pm 30 \mathrm{~min}$ ) and precipitated for $24 \mathrm{~h}$. Next, the upper layer of the ethanol mixture was taken, then it was put in a $1 \mathrm{~L}$ evaporation flask and fitted on the evaporator [23]. Afterward, a water bath was made, then all the tools were installed, including a rotary evaporator. The water bath was set to $90^{\circ} \mathrm{C}$ and connected to electricity. Ethanol solution was allowed to separate from the existing active substance in the flask, and the solution was observed until the flow of ethanol stops dripping $( \pm 1.5$ to $2 \mathrm{~h}$ for 1 container tube). Extraction results were put in a plastic bottle and stored in a freezer.

\section{Immunohistochemistry}

The scar tissue was taken then IL-1 expression and macrophages number was identified using immunohistochemistry staining. IL-1expression was stained using IL-1 antibody (H-153): sc7884, and macrophages number was stained using macrophages antibody (mac387): sc-66 204 Santa Cruise Inc. The percentage of IL-1 expression was determined by measuring the area of brownish color on the intra- and extra-cellular. IL-1 expression was observed under a light microscope [24]. Moreover, the macrophage was determined as a round or oval cell with an irregular edge, kidney nucleus, and brown appearance in the area of the cytoplasm of the cell with a purplish blue nucleus under a light microscope [25]. The number of IL-1 and macrophage expression was observed in 10 visual fields which were further recorded, counted and averaged.

\section{Analysis}

The number of IL-1 and macrophages expression was statistically analyzed by IBM SPSS 20 software. Normality test was conducted using a Shapiro-Wilk test with $\alpha>0.05$. Homogeneity test was done using the Levene test homogeneity of variances with $\alpha>0.05$. If the data were normal and homogeneous, it could be continued with a parametric test of one-way ANOVA $[26,27]$ and continued using Tukey honestly significant difference (HSD) post hoc test [26,27].

\section{RESULTS}

\section{Expression of interleukin 1}

Interleukin 1 is one of the cytokines which is the main molecular activity of initial inflammation; expression of IL-1 in each group is depicted in Fig. 1. The result of observations of IL-1 expression presented in Table 1. Homogeneity and normality test for IL-1 expression showed

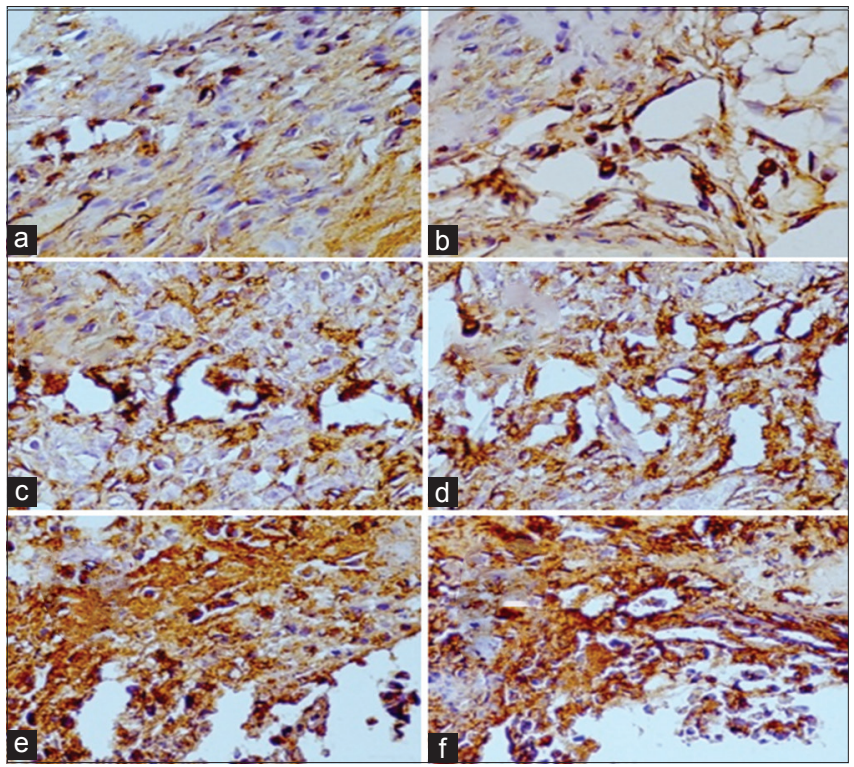

Fig. 1: Interleukin-1 expression from second-degree burn tissues that is treated using: (a) $\mathrm{NaCl} 0.9 \%$; (b) silver sulfadiazine;

(c) hydrogel; (d) extract ethanol of Cincau leaves 40\%; (e) extract ethanol of Cincau leaves $50 \%$; and (f) extract ethanol of Cincau leaves $60 \%$ 
that data were normally distributed and homogeneous ( $p>0.05$ ), which allowed to be analyzed by one-way ANOVA test. ANOVA test of IL-1 expression showed that there was a significant difference among the groups $(\mathrm{p}<0.05)$. The post hoc Tukey HSD analysis with a confident interval of $95 \%$ showed that there was a significant difference on the IL-1 expression between the P3 and P4 with the control group ( $\mathrm{p}<0.05$; $\mathrm{p}<0.05$ ). There was no significant difference observed among P3 and P4 with P2 group. P5 showed the lowest expression of IL-1 and was also different from the control and treatment groups.

\section{Macrophage expression number}

Macrophage is the phagocyte cell that has a primary function in inflammation. The macrophage number was showed in Fig. 2. The quantitative number of macrophage cell showed in Table 2 . The data were normally distributed and homogeneous ( $p>0.05)$, then followed by ANOVA analysis for macrophage number. The ANOVA analysis showed that there was a significant difference among groups $(\mathrm{p}<0.05)$. The post hoc Tukey HSD analysis on the number of macrophages showed a significant difference between the treatment group P3 and $\mathrm{P} 4$ with the control group $(\mathrm{p}<0.05)$. There was no significant difference observed among P3 and P4 groups with the comparison groups (P1 and P2) that used SSD and hydrogel as standard therapy. The group treated with Cincau extract $60 \%$ (P5) had the highest macrophages average. There was a significant difference observed in macrophage expression number between P5 with the whole group.

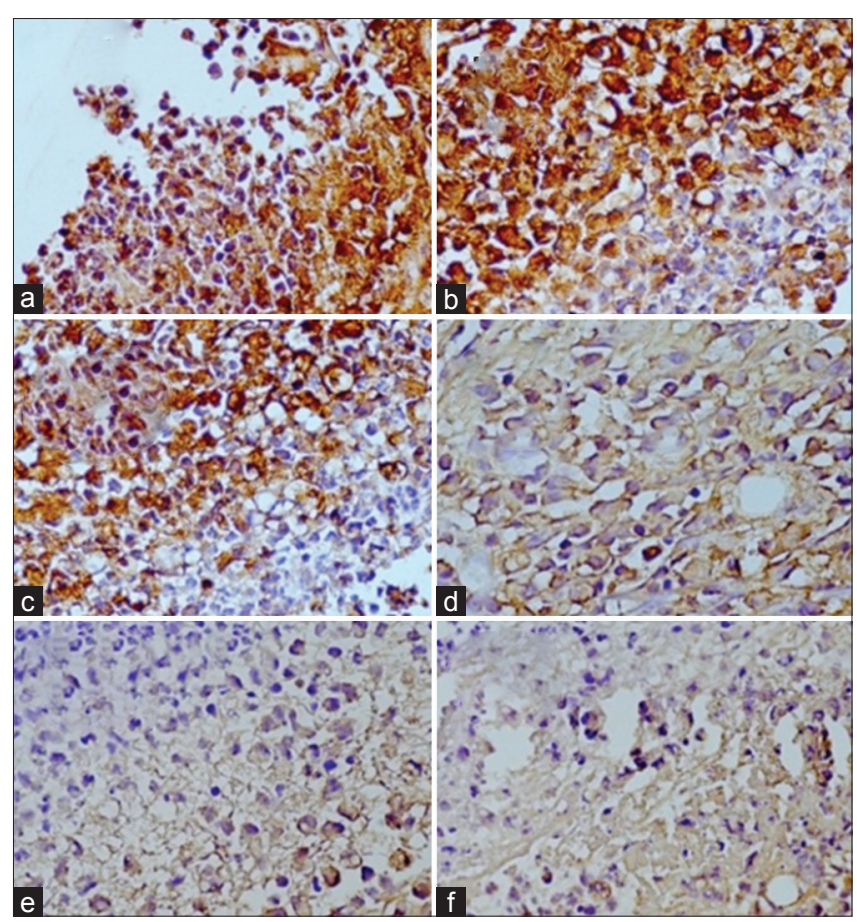

Fig. 2: Macrophages expression from second-degree burn tissues that are treated using: (a) $\mathrm{NaCl} 0.9 \%$; (b) silver sulfadiazine;

(c) hydrogel; (d) extract ethanol of Cincau leaves 40\%; (e) extract ethanol of Cincau leaves $50 \%$; and (f) extract ethanol of Cincau leaves $60 \%$

Table 1: Mean of interleukin-1 expression

\begin{tabular}{ll}
\hline Groups & Mean \pm SD \\
\hline NaCl 0,9\% (K) & $22.17 \pm 1.47$ \\
silver sulfadiazine (P1) & $16.67 \pm 3.14$ \\
Hydrogel (P2) & $12.67 \pm 2.65$ \\
Cincau 40\% (P3) & $12.17 \pm 2.13$ \\
Cincau 50\% (P4) & $9.50 \pm 1.76$ \\
Cincau 60\% (P5) & $5.50 \pm 1.37$ \\
\hline
\end{tabular}

Sample size $(\mathrm{n}=30)$. * ${ }^{*}$ sgnificant different between P3 and P4 with control group

\section{DISCUSSION}

In this study, wound tissue was analyzed on the $4^{\text {th }}$ day after the injury. The $4^{\text {th }}$ day after the injury is an appropriate time to know the existence of a pro-inflammatory cytokine and macrophages migration $[7,23,24]$.

On the $4^{\text {th }}$ day post-injury, the pro-inflammatory cytokines such as IL-1 have a role in the migration of macrophages, although this cytokine physiologically started to decline [28-30]. The declining of IL-1 showed in the results where IL-1 expression decreased in the whole group. Furthermore, there was a significant decrease in the groups treated with Cincau leaf extract 40\% (P3) and 50\% (P4) compared to that of the control group. Expression of IL-1 between the P3 and P4 with the group treated with standard therapy hydrogels (P2) did not show a significant difference. Similar IL-1 expression in P2, P3, and P4 groups indicated that the compound in the Cincau leaves (polysaccharide pectin) has the same effect as the component in the hydrogel.

According to Zohdi et al., treatment for injury with hydrogel can decrease IL-1 on the $7^{\text {th }}$ day of burns [31]. Similar results were shown in this study, the decrease in the expression of IL-1 observed in the group treated by hydrogels (P2). A decreased expression of IL-1 was also found in the group treated with Cincau leaves extract. Cincau leaves contain antioxidant such as flavonoid that might influence the reduction of IL-1 [19,31]. More specifically Kusmardiyani et al. revealed that flavonoids contained in the leaves of green grass jelly are a flavonol 3-oglikosida [17]. A previous study by Chen et al. revealed that flavonoids in Lonicera japonica could reduce pro-inflammatory cytokines in the wound excision in day 1 and 9 post-creation of the wound [32]. Another study mentioned that the flavonoids (kaempferol) can help the healing of burns by suppressing pro-inflammatory cytokines [33].

Cincau (C. barbata) leaves are a herb that contains antioxidants such as flavonoids and alkaloids [34]. Flavonoid contained in the Cincau leaves also has the ability to increase the migration of macrophages as inflammatory cells to the injured tissues $[35,36]$. It is comparable to a study by Yuneda (2011) that showed flavonoids could increase the number of macrophages that migrate along with the gum after tooth revocation [37]. Macrophage migration might also affected by the humidity of the wound surface $[13,38,39]$. Moist wound conditions will increase cell migration into the wound area; during this time, monocytes migration from the intravascular would infiltrate and differentiate into macrophages to the injured tissue $[38,40]$. This process leads to an increase in the number of macrophages in the tissue. Moisture in the wound area can be affected by topical therapy that binds wound exudate fluid (hydrophilic dressing) $[9,40]$.

Cincau leaves also contain pectin, which is a hydrophilic polysaccharide [41]. The results showed that the groups treated with ethanol extract of leaves of green grass jelly $40 \%$ and $50 \%$ (P3 and P4) showed no significant difference with the group treated by the standard treatment SSD and hydrogel (P1 and P2) in the migration of macrophages. P5, the group treated with the ethanol extract of green grass jelly leaves $60 \%$ showed the highest increase in macrophage migration and had a significant difference with the group treated with the standard treatment SSD and hydrogel (P1 and P2).

The number of macrophages on the third day after inflammation has normally increased, however, burns have specific characteristics when compared to other clean wounds such as surgical wound [6]. In scalds the skin defensive decreases due to damage to epidermal and dermal cells [5]. Macrophage migration is influenced by components of adhesion molecules, one of them is intracellular adhesion molecule (ICAM1) [42]. ICAM1 is activated by pro-inflammatory cytokines such as IL-1, IL6, interferon- $\gamma$, and tumor necrosis factor- $\alpha[6,7]$. These cytokines induce adhesion molecules that influence macrophages to migrate into the tissue [42]. There is a discrepancy in the present study; between the expression of IL-1 and the number of macrophages. The 
decline of IL-1 in the group treated with Cincau extract using 60\% (P5) is not consistent with the increasing number of macrophage migration in the same group.

This discrepancy could be explained by other research findings which showed that the moist condition of wound surface can activate ICAM1 [43]. Wang et al. revealed that moisturizing with a vacuum could increase the ICAM1 in the wound site. It also mentioned that the increase in ICAM1 was followed by an increase in the migration of macrophage [43].

\section{CONCLUSIONS}

This study concluded that topical treatment with ethanol extract of Cincau leaves could decrease the expression of IL-1 and increased the number of macrophages in burns wound tissue. Flavonoids are components contained in the ethanol extract of Cincau leaves which have an effect IL-1 expression decrease and macrophages migration increase. Cincau leaves also contain pectin hydrophilic polysaccharide that is capable on wound liquid exudate binding to maintain surface moisture and facilitate the migration of macrophages to the wound site.

\section{ACKNOWLEDGMENTS}

This research was supported by the Biochemistry Laboratory of Medical Faculty of Brawijaya University.

\section{AUTHORS' CONTRIBUTIONS}

The first author was the conductor of the research, and the other authors technically support the experiment and the article writing process. Dina Dewi SLI: Conductor of the research and writing process. Wibi Riawan: Technical data support on the laboratory. Ika Setyo Rini: Technical data support on the laboratory. Titin Andri Wihastuti: Technical support on the writing processIka Fitri Aprilianti: Technical data support on the laboratory. Retty Ratnawati: Supervisor and consultant. Handono Kalim: Supervisor and consultant. Karyono Mintareom: Supervisor and consultant. Loeki Enggar Fitri: Supervisor and consultant.

\section{ETHICS APPROVAL AND CONSENT TO PARTICIPATE}

This research was approved by the Ethical Clearance team of Medical Faculty of Brawijaya University.

\section{AVAILABILITY OF DATA AND MATERIALS}

We cannot publish raw data source because there are a lot of data content and any data associated with other research that cannot be included in this article.

\section{FUNDING}

Publication of this article was funded by DPP/SPP from the Medical Faculty of Brawijaya University.

\section{CONFLICTS OF INTEREST}

There were no conflicts of interest in this research process

\section{REFERENCES}

1. Penelitian B. Laporan Hasil Riset Kesehatan Dasar (RISKESDAS) Provinsi Jawa Barat Tahun 2007. Jakarta:Balitbangkes; 2009.

2. Pujisriyani P, Wardhana A. Epidemiology of burn injuries in Cipto Mangunkusumo hospital from 2009 to 2010. J Plast Rekonstr 2012;1:5. Available from: http://www.jprjournal.com/index.php/jpr/ article view/110.

3. Moenadjat Y. Luka Bakar: Pengetahuan Klinik Praktis. $3^{\text {rd }}$ ed. Jakarta: Balai Penerbitan Fakultas Kedokteran Universitas Indonesia; 2003.

4. Moenadjat Y. Luka Bakar: Masalah dan Tata Laksana. Jakarta: Balai penerbit FKUI; 2009.

5. Tiwari VK. Burn wound: How it differs from other wounds? Indian J Plast Surg 2012;45:364-73.
Table 2: Mean of macrophage number

\begin{tabular}{ll}
\hline Groups & Mean \pm SD \\
\hline NaCl 0.9\% (K) & $9.67 \pm 2.06$ \\
Silver sulfadiazine (P1) & $11.00 \pm 1.78$ \\
Hydrogel (P2) & $12.50 \pm 1.87$ \\
Cincau 40\% (P3) & $14.17 \pm 2.71$ \\
Cincau 50\% (P4) & $14.67 \pm 4.08$ \\
Cincau 60\% (P5) & $19.83 \pm 2.04$ \\
\hline
\end{tabular}

Sample size $(\mathrm{n}=30)$. *significant different between P3 and P4 with control group

6. Koh TJ, DiPietro LA. Inflammation and wound healing: The role of the macrophage. Expert Rev Mol Med 2011;13:e23.

7. Evers LH, Bhavsar D, Mailänder P. The biology of burn injury. Exp Dermatol 2010;19:777-83.

8. Smeltzer S, Bare B. Buku Ajar Keperawatan Medikal Bedah Brunner and Suddarth. $8^{\text {th }}$ ed. Jakarta: EGC; 2002.

9. McGuiness W, Vella E, Harrison D. Influence of dressing changes on wound temperature. J Wound Care 2004;13:383-5.

10. Nettina S. Lippincott Manual of Nursing Practice. Philadelphia, PA: Lippincott William and Wilkins; 2010.

11. Erizal E. The effect of hydrogel dressing copolymer poli (Vinylpirrolidone) (Pvp) k-carrageenan prepared by radiation and healing times on the radius reductions burn injuried of wistar white rat. Indones J Chem 2010;8:271-8.

12. Edwards J. Hydrogels and their potential uses in burn wound management. Br J Nurs Mark Allen Publ 2010;19:S12-6.

13. Dhivya S, Padma VV, Santhini E. Wound dressings a review. Biomed 2015;5:22. Available from: http:/www.globalsciencejournals.com/ article/10.7603/s40681-015-0022-9.

14. Suriadi S. Perawatan Luka. Jakarta: Sagung Seto; 2004.

15. Arkarapanthu A, Chavasit V, Sungpuag P, Phuphathanaphong L. Gel extracted from Khruea-ma-noi (Cyclea barbata Miers) leaves: Chemical composition and gelation properties. J Sci Food Agric 2005;85:1741-9.

16. Sunanto H. Budidaya Cincau. Yogyakarta: Kanisius; 1995.

17. Kusmardiyani S, Insanu M, Asyhar MA. Effect a glycosidic flavonol isolated from green grass jelly (Cyclea barbata Miers) Leaves. Proc Chem 2014;13:194-7.

18. Arun M, Satish S, Anima P. Herbal boon for wounds. Wounds 2013;6:8.

19. Chen ZC, Wu SS, Su WY, Lin YC, Lee YH, Wu WH, et al. Antiinflammatory and burn injury wound healing properties of the shell of haliotis diversicolor. BMC Complement Altern Med 2016;16:487.

20. Septianingsih DP. Gel Daun Cincau Rambat (Cyclea barbata Miers) Sebagai Bahan Pengikat Tablet Antalgin. Purwokerto: Universitas Muhammadiyah Purwokerto; 2010. Available from: http://www. repository.ump.ac.id/2798.

21. Hong SC, Oh MH, Lee H, Park YS, Kim NY, Park SH, et al. Pectinase modified red ginseng (Gs-E3d) inhibit Nf-ǏšB translocation and nitric oxide production in lipopolysaccharide-stimulated raw 264.7 cells. Int J Pharm Pharm Sci 2015;22:322-6.

22. Smeltzer SC, Bare BG, Hinkle JL, Cheever KH. Brunner and Suddarth's Textbook of Medical Surgical Nursing. Philadelphia, PA: Lippincott Williams and Wilkins; 2010. p. 2362.

23. Rahayu R, Taslim EM, Sumarno S. Pembuatan serbuk daun cincau hijau rambat Cyclea barbata L. Miers menggunakan proses maserasi dan foam mat drying. J Teknol Kim Dan Ind 2013;2:24-31.

24. Hübner G, Brauchle M, Smola H, Madlener M, Fässler R, Werner S, et al. Differential regulation of pro-inflammatory cytokines during wound healing in normal and glucocorticoid-treated mice. Cytokine 1996;8:548-56.

25. Gordon S, Plüddemann A, Martinez Estrada F. Macrophage heterogeneity in tissues: Phenotypic diversity and functions. Immunol Rev 2014;262:36-55

26. Sarjono H, Julianita W. SPSS vs LISREL: Sebuah Pengantar, Aplikasi untuk Riset. Jakarta: Salemba Emapt; 2011.

27. Dahlan M. Statistik untuk Kedokteran dan Kesehatan Deskriptif, Bivariat dan Multivariat Dilengkapi dengan Menggunakan SPSS. Jakarta: Salemba Medika; 2009.

28. Leong M, Phillips LG. Wound Healing. Thoracic Key; 2016. Available from: https://www.thoracickey.com/wound-healing.

29. Li J, Chen J, Kirsner R. Pathophysiology of acute wound healing. Clin Dermatol 2007;25:9-18.

30. Rider P, Carmi Y, Guttman O, Braiman A, Cohen I, Voronov E, et al. IL- $1 \alpha$ and IL- $1 \beta$ recruit different myeloid cells and promote different 
stages of sterile inflammation. J Immunol 2011:187:4835-43.

31. Zohdi RM, Zakaria ZA, Yusof N, Mustapha NM, Abdullah MN. Sea cucumber (Stichopus herrmanni) based hydrogel to treat burn wounds in rats. J Biomed Mater Res B Appl Biomater 2011;98:30-7.

32. Chen WC, Liou SS, Tzeng TF, Lee SL, Liu IM. Wound repair and anti-inflammatory potential of Lonicera japonica in excision woundinduced rats. BMC Complement Altern Med 2012;12:226.

33. Park BK, Lee S, Seo JN, Rhee JW, Park JB, Kim YS, et al. Protection of burn-induced skin injuries by the flavonoid kaempferol. BMB Rep 2010;43:46-51.

34. Elya BK, Shodiq AM. Aktivitas antioksidan ekstrak dan fraksi daun cincau hijau rambat (Cyclea barbata Miers.) serta identifikasi golongan senyawa dari fraksi yang paling aktif. J Bahan Alam Indones 2012;8:12-9.

35. Kotian SR, Pai KS, Nayak JK, Bangera H, Prasad K, Bhat KM. Biomechanical, biochemical and histological evidences for wound healing properties of Indian traditional medicines. Int J Pharm Pharm Sci 2015;7:163-71

36. Ranganathaiah P, Hanumanthappa M, Venkatarangaiah K. Evaluation of in vitro anti inflammatory activity of stem bark extracts of Mesua ferrea Linn. Int J Pharm Pharm Sci 2016;8:173-7.
37. Yuneda Y. Efek Pemberian Jus Buah Belimbing Manis (Averrhoa carambola L.) Terhadap Peningkatan Jumlah Makrofag pada Soket Gigi Tikus (Rattus novergicus) Strain Wistar Pasca Pencabutan. Sarjana Thesis, Universitas Brawijaya; 2013.

38. Bashir MM, Afzal S. Comparison of normal saline and honey dressing in wound preparation for skin grafting. Ann King Edward Med Univ 2010;16:120.

39. Singer AJ, Clark RA. Cutaneous wound healing. N Engl J Med 1999;341:738-46.

40. Sood A, Granick MS, Tomaselli NL. Wound dressings and comparative effectiveness data. Adv Wound Care (New Rochelle) 2014;3:511-29.

41. Mackaman P, Tangsuphoom N, Chavasit V. Effect of extraction condition on the chemical and emulsifying properties of pectin from Cyclea barbata Miers leaves. Int Food Res J 2014;21:799-806. Available from: http://www.ifrj.upm.edu.my/.pdf.

42. Greaves NS, Ashcroft KJ, Baguneid M, Bayat A. Current understanding of molecular and cellular mechanisms in fibroplasia and angiogenesis during acute wound healing. J Dermatol Sci 2013;72:206-17.

43. Wang W, Pan Z, Hu X, Li Z, Zhao Y, Yu AX, et al. Vacuum-assisted closure increases ICAM-1, MIF, VEGF and collagen I expression in wound therapy. Exp Ther Med 2014;7:1221-6. 